Maegorzata Szemiel

Uniwersytet Papieski Jana Pawła II w Krakowie

\title{
ZnACZENIE POGRZEBU DLA PRZEŻYWANIA ŻAŁOBY
}

\section{Rytuał}

W naturę człowieka wpisany jest rytuał. Społeczeństwo potrzebuje uświęcenia, podkreślenia czy też upamiętnienia konkretnych wydarzeń z życia jego członków określonymi obrzędami. Zachowania rytualne wyrażają zmianę statusu społecznego, przejście do kolejnego etapu życia (np. zawarcie małżeństwa), włączenie do wspólnoty (np. inicjacja) czy też osiągnięcie określonego poziomu społecznego. Obrzędy ukazują przemijalność czasu ludzkiego, nadają sens codziennym czynnościom, a przede wszystkim wyrażają uczucia i przekonania, które trudno jest inaczej uchwycić i jasno zobrazować.

Śmierć bliskiej osoby jest jednym z najtrudniejszych wydarzeń w życiu człowieka. Zjawisko śmierci stanowi tajemnicę, którą niełatwo jest zrozumiećz. Rytuał związany z pochowaniem zmarłego pomaga w przyjęciu śmierci, konfrontacji z tym, co się wydarzyło,

\footnotetext{
${ }^{I}$ Por. B. Nadolski, Leksykon liturgii, Poznań 2006, s. I 333-I 334.

${ }^{2}$ Por. Z. Rudnicki, Śmierí jako kres życia ludzkiego, w: Wybrane problemy osób starszych, red. A. Nowicka, Kraków 2006, s. I05.
} 
pogodzeniu się zarazem z utratą, jak i z nową sytuacją ${ }^{3}$. Zazwyczaj człowiek nie myśli o śmierci, dopóki osobiście się z nią nie zmierzy lub nie dotknie ona osoby z jego najbliższego otoczenia.

Dzisiaj tematyka śmierci jest zmarginalizowana, często nawet kamuflowana ${ }^{4}$. Kult ciała, powstrzymywanie starzenia się organizmu, a co za tym idzie, wydłużania życia odwraca uwagę od śmierci5. Banalizowanie śmierci poprzez tworzenie jej karykaturalnych obrazów czy żarty z niej niesie jasny przekaz - śmierć nie jest „poważna”. Pomimo jej codziennej obecności w tragicznych wydarzeniach w telewizji i gazetach jest ona tematem tabu w ścisłym tego słowa znaczeniu? W rodzinie czy w pracy rzadko poruszane są „zagadnienia śmiertelne”, nie rozmawia się o własnej, „mojej”śmierci. Kto zawczasu planuje swój pogrzeb? Obmyśla, jak będzie ubrany, jaki chce pomnik, kwiaty, znicze? Nie spisujemy w wieku I4, 27 czy 40 lat testamentu o tym, jak mają wyglądać przygotowania do własnego pogrzebu. Niezbyt często w naszych myślach czy rozmowach pojawia się problematyka powiązana ze śmiercią. Dopiero fakt czyjejś śmierci uruchamia w nas myśl „ona istnieje”. Jej nieobecność w zwyczajnej codzienności, w życiu

3 Por. J. Pawlik, Zatrzymać i oddalić. Podwójna logika obrzędowości żatobnej, w: Śmierć $i$ wiara w życie pośmiertne w świetle nauk przyrodniczych $i$ humanistycznych, red. M. Machinek, Olsztyn 2003, s. I6 I.

${ }^{4}$ Por. M. Ogryzko-Wiewiórowska, Desocjalizacja umierania. Aspekty socjologiczne kresu życia, w: Śmierć $i$ wiara w życie pośmiertne w świetle nauk przyrodniczych i humanistycznych, red. M. Machinek, Olsztyn 2003, s. 79.

5 Por. J. Barański, Śmierć i zmysty. Doświadczenie śmiertelnej choroby i śmierci na przestrzeni wieków, w: Śmierć $i$ wiara w życie pośmiertne w świetle nauk przyrodniczych i humanistycznych, red. M. Machinek, Olsztyn 2003, s. I 39.

${ }^{6}$ Por. M. Ogryzko-Wiewiórowska, Desocjalizacja umierania. Aspekty socjologiczne kresu życia..., dz. cyt., s. 8I .

7 Por. J. Makselon, Fatum czy szansa? Postawy wobec wtasnej śmierci, w: Śmierć i wiara w życie pośmiertne..., red. M. Machinek, dz. cyt., s. 36. 
osobistym, czyni z niej „demona”. Boimy się śmierci, uważamy nawet, że lepiej nie poruszać tematyki śmierci, bo można ją w ten sposób do siebie przywołać ${ }^{8}$. Człowiek przypomina sobie o śmierci, gdy się już zjawi, i to zwykle bez zapowiedzi i zaproszenia. Współczesny świat cechuje „śmierć śmierci”.

Nieakceptacja śmierci jako naturalnej części życia ludzkiego powoduje, że realne zetknięcie się z nią jest wielkim przeżyciem. Rytuał pogrzebu, czyli czynności związane z pochowaniem zmarłego, sam pogrzeb stają się pewnego rodzaju „mediacją” pomiędzy bliskimi a śmiercią ${ }^{\mathrm{I}}$. Obrzędy łagodzą wstrząs, jakim dla krewnych i znajomych jest śmierć bliskiej im osoby. Można powiedzieć, że zachowania rytualne służą oswojeniu się ze śmiercią, zaakceptowaniu jej samej, faktu, że jest ona zjawiskiem naturalnym i że zabierze każdą istotę ludzką z ziemskiego świata ${ }^{\text {II }}$. Obrzędowość jest również pewnego rodzaju sposobem wytłumaczenia sobie, że śmierć wpisuje się w normalny porządek życia i w ludzki los.

\section{2. $\dot{Z}$ ałoba}

Rytuał wyraża to, co niewyrażalne, pomaga w przyjęciu bólu, który pojawił się wraz ze stratą, i zaakceptowaniu całej gamy uczuć,

\footnotetext{
${ }^{8}$ Por. J. Makselon, Fatum czy szansa? Postawy wobec wtasnej smierci, w: Śmieŕ́ i wiara w życie pośmiertne..., red. M. Machinek, dz. cyt.,, s. 39.

${ }_{9}$ Por. J. Barański, Śmierć i zmysty. Doświadczenie śmiertelnej choroby i śmierci na przestrzeni wieków..., dz. cyt., s. I39.

ro Por. J. Pawlik, Zatrzymać i oddalić. Podwójna logika obrzędowości żatob$n e j . . .$, dz. cyt., s. I6o.

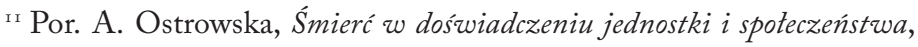
Warszawa I 999, dz. cyt., s. I3-I6.
} 
często ambiwalentnych. Dlatego akty obrzędowe są konieczne do prawidłowego przeżycia żałoby, stanowią jej nieodłączny element. Człowiek, będąc istotą postrzegającą rzeczywistość na różne sposoby, potrzebuje bodźców różnego rodzaju, nie wystarczy tylko komunikat: on/ona zmarła. Konkretne czynności pogrzebowe pomagają w zrozumieniu i uzmysłowieniu sobie, że bliska osoba rzeczywiście nie żyje.

Żałoba rozpoczyna się już $\mathrm{w}$ chwili śmierci, a nie dopiero po pogrzebie ${ }^{\mathrm{I} 2}$. Jest przyjęciem społecznych wzorów zachowań związanych ze śmiercią, których źródłem jest tradycja i zwyczaje. Żałoba jest zjawiskiem kulturowym, podyktowanym przez ludzkie potrzeby. Wyraża się w żalu po stracie ukochanej osoby, przeżywanym bólu, reakcjach fizjologicznych (kłopoty ze snem, łaknieniem, bóle głowy) i psychologicznych (huśtawka nastrojów, lęk, stany depresyjne). Zazwyczaj oba rodzaje reakcji występują równocześnie. Czas trwania żałoby jest zależny od głębokości relacji i przyczyny śmierci. Żałoba nie powinna trwać zbyt długo, gdyż oznaczałoby to, że bliscy osoby zmarłej nie potrafią przeorganizować dotychczasowego życia ${ }^{\mathrm{I} 3}$.

Żałoba jest mocno naznaczona lękiem o zmarłego, jego bliscy odczuwają niepewność, czy na pewno ich krewny nie żyje, pojawia się obawa, że może lekarze pomylili się, stwierdzając zgon. Odrzuca się śmierć ukochanego człowieka, zaprzecza jej. Dlatego dawniej jedną $z$ form upewnienia się co do zgonu było czuwanie przy zmarłym. Bliscy nie tylko modlili się za zmarłego, ale także obserwowali, czy nie pojawią się oznaki życia. Stąd zmieniano

\footnotetext{
${ }^{12}$ Por. J. Pawlik, Zatrzymać i oddalić. Podwójna logika obrzędowości żatobnej..., dz. cyt., s. I 68.

${ }^{3}$ Por. J. Pawlik, Zatrzymać i oddalić. Podwójna logika obrzędowości żatob$n e j . . .$, dz. cyt., s. I68-169.
} 
się podczas czuwania, by nie było momentu, w którym zostałby on sam. Współcześnie obrzęd ten zanika, jednak pojawiają się wątpliwości, nawet wśród lekarzy. Większość ludzi umiera w szpitalu, gdzie są wyznaczone godziny odwiedzin pacjentów, dlatego często zdarza się, że rodzina nie jest obecna przy śmierci bliskiej im osoby. Szpital nie zapewnia miejsca na czuwanie przy zmarłym, dlatego przeżywanie żałoby jest utrudnione. Wydłuża się etap zrozumienia, że bliska osoba już nigdy nie przywita się z nami ${ }^{\text {I4 }}$.

Trudniej jest przyjąć śmierć bliskiego, kiedy jest on sztucznie utrzymywany przy życiu przez aparaturę medyczną, a lekarze stwierdzili śmierć mózgową ${ }^{15}$. Rodzina widzi, że podnosi się klatka piersiowa kochanej osoby, a to przecież znak, że oddycha, że pojawiają się ruchy palców u rąk, co sugeruje, że może za chwilę otworzy oczy. Bardzo trudno wtedy zrozumieć, że ta osoba już nigdy się nie obudzi ${ }^{16}$. Następuje rozdźwięk pomiędzy tym, co jest widoczne, a tym, co ukryte, i trzeba się zdać na opinię specjalistów.

Dla procesu żałoby ważne jest ciało zmarłego. Ono jest nośnikiem wspomnień, dlatego widok zwłok tak rozczula bliskich, ponieważ to ciało wiąże się z konkretnymi wydarzeniami i relacjami $^{\mathrm{r}}{ }^{\mathrm{r}}$. Na tym etapie żałoby rodzą się pytania dotyczące życiażycia w chwili obecnej i w przyszłości, a także niezrealizowanych celów, własnej śmierci, sensu istnienia człowieka, jego wartości oraz znaczenia osoby zmarłej. Bliscy próbują „zatrzymać ciało”

\footnotetext{
${ }^{\text {I4 }}$ Por. J. Pawlik, Zatrzymać i oddalic. Podwójna logika obrzędowości żatob$n e j . . .$, dz. cyt., s. I62-I63.

${ }^{15}$ Por. J. Barański, Śmierć i zmysty. Doświadczenie śmiertelnej choroby i śmierci na przestrzeni wieków..., dz. cyt., s. I39.

${ }^{16}$ Por. M. Ogryzko-Wiewiórowska, Desocjalizacja umierania. Aspekty socjologiczne kresu życia..., dz. cyt., s. 78.

${ }^{17}$ Por. P. Morciniec, Bioetyka personalistyczna wobec zwtok ludzkich, Opole 2009 , s. I 32.
} 
poprzez obchodzenie się z nim z delikatnością, szacunkiem, powagą, bez pośpiechu ${ }^{18}$. W tym sposobie obchodzenia się przez bliskich $\mathrm{z}$ ciałem zmarłego ukazuje się ich pietyzm i wiara $\mathrm{w}$ to, że życie człowieka jest wartością, a szczątki ludzkie symbolizują wartość, którą stanowiła osoba ludzka za swego życia ${ }^{19}$. Pietyzm przede wszystkim wyraża się w moralnym obowiązku pochowania zwłok ${ }^{2 \circ}$, dlatego tak ważne są czynności związane $z$ organizacją pogrzebu. Podejście do zwłok ludzkich z szacunkiem i miłością ułatwia pielęgnowanie pamięci o zmarłym ${ }^{21}$. Grzebanie ciała zmarłych jest dziełem miłosierdzia, o którym jest mowa w Księdze Tobiasza, zalicza się je do uczynków miłosierdzia względem ciała, ponieważ szacunek dla zwłok ludzkich jest obowiązkiem chrześcijańskim²2.

Bliscy zmarłego okazując szacunek dla martwego ciała, oczekują tego także od osób, które się nim zajmują, personelu medycznego czy pracowników zakładu pogrzebowego. $Z$ tej racji ważne zadbanie o estetyczny wygląd zwłok, obchodzenie się nimi z delikatnością i umożliwienie godnego pożegnania się ze zmarłym²3. Osoby, dla których śmierć ze względu na wykonywaną pracę jest czymś zwyczajnym, w obecności bliskich powinny kontrolować

\footnotetext{
${ }^{18}$ Por. J. Pawlik, Zatrzymać i oddalić. Podwójna logika obrzędowości żatobnej..., dz. cyt., s. I62.

${ }^{19}$ Por. P. Morciniec, Bioetyka personalistyczna wobec zwtok ludzkich, dz. cyt., s. $5 \mathrm{I}$.

${ }^{20}$ Por. P. Morciniec, Bioetyka personalistyczna wobec zwtok ludzkich, dz. cyt., s. 54 .

${ }^{21}$ Por. P. Morciniec, Bioetyka personalistyczna wobec zwtok ludzkich, dz. cyt., s. 54 .

${ }_{22}^{2}$ Por. Tb i, r6-г 8; KKK 2300.

${ }_{23}$ Por. P. Morciniec, Bioetyka personalistyczna wobec zwtok ludzkich, dz. cyt., S. 55 .
} 
swe rutynowe zachowanie. W szpitalach nadal zdarza się, że nie umożliwia się spokojnego pożegnania się rodzicom z poronionym dzieckiem oraz że są oni świadkami niewłaściwego obchodzenia się z jego ciałem ${ }^{24}$. Dla nich zmarły jest nadal żywy, obecny w ich myślach i rozmowach, dlatego bliscy szczególną uwagę zwracają na każdy gest osób obcych wobec zmarłego. Stąd wynika tak wiele trudności, gdy jest możliwość pobrania narządów. Rodzina obawia się wyglądu zwłok po dokonanych w związku z tym czynnościach medycznych ${ }^{25}$. Naruszenie integralności zwłok w odbiorze bliskich oznacza najczęściej ich instrumentalizację ${ }^{26}$. Wcześniejsza bliska relacja ze zmarłym nie dopuszcza możliwości, żeby poszczególne części jego ciała mogły służyć drugiej osobie jako przeszczepione organy.

Wartość ciała zmarłego dla jego bliskich jest na tyle ważna, że bez niego proces przeżywania żałoby jest znacznie utrudniony. Ujrzenie zwłok osoby zmarłej daje krewnym pewność, że ta osoba nie żyje. Cierpienie rodziców dzieci poronionych we wczesnym stadium rozwoju staje się większe, jeśli nie mogli zobaczyć ciała ich zmarłego dziecka oraz nie wydano im go, by mogli je pochować. Ciało jest konieczne do procesu żałoby, by można było je opłakać, pożegnać się z nim i podzielić się z innymi wiadomością, że bliska osoba zmarła ${ }^{27}$. Wydawana przez lekarza karta zgonu,

${ }^{24}$ Por. B. Imielska, Umartych pogrzebać. Zagadnienie pochórwku dzieci poronionych lub martwo urodzonych w prawie kanonicznym oraz ustawodawstwie polskim, Bielsko-Biała 2014, s. 85 .

${ }_{25}$ Por. P. Morciniec, Bioetyka personalistyczna wobec zwtok ludzkich, dz. cyt., s. 57 .

${ }^{26}$ Por. P. Morciniec, Bioetyka personalistyczna wobec zwtok ludzkich, dz. cyt., s. 59 .

${ }_{27}$ Por. B. Imielska, Umartych pogrzebać. Zagadnienie pochówku dzieci poronionych..., dz. cyt., s. 85 . 
która jest konieczna do otrzymania aktu zgonu i pochowania zwłok ludzkich, staje się publicznym potwierdzeniem śmierci ${ }^{28}$. W sytuacji, gdy ciała nie odnaleziono z powodu okoliczności śmierci, krewni nie mają pewności, że osoba umarła. Tli się w nich nadzieja na jej powrót, dlatego ciągle jej oczekują. Ciało jest gwarantem „obecności” zmarłego na jego pogrzebie ${ }^{29}$.

\section{Pogrzeb}

Obrzędy pogrzebu należy sprawować zgodnie z normami prawa kanonicznego: „Wierni zmarli powinni otrzymać pogrzeb kościelny zgodnie z przepisem prawa”, jak i prawa liturgicznego: „Pogrzeb kościelny, w którym Kościół wyprasza duchową pomoc zmarłym, okazuje szacunek ich ciału i równocześnie żywym niesie pociechę nadziei, należy odprawiać z zachowaniem przepisów liturgicznych"3०. Obrzędy pogrzebowe uwzględniają zarówno osobę, która umarła, poprzez wypraszanie dla niej życia wiecznego i oddanie szacunku jego ciału, oraz rodzinę zmarłego, okazując im pociechę i dając nadzieję.

Teksty ceremonii pogrzebu wyrażają wsparcie dla bliskich zmarłego:

Zgromadziliśmy się, aby pożegnać naszego brata (naszą siostrę) N. Jego (jej) śmierć napełniła bólem jego (jej) rodzinę i wielu z nas. Wszyscy bierzemy udział w ich cierpieniu i wyrażamy nasze współczucie. Chcemy

${ }^{28}$ Por. B. Imielska, Umartych pogrzebać. Zagadnienie pochórwku dzieci poronionych..., dz. cyt., s. 89 .

${ }^{29}$ Por. J. Pawlik, Zatrzymać i oddalić. Podwójna logika obrzędowości żatobnej..., dz. cyt., s. I 65 .

${ }^{\circ} \mathrm{Kan}$. I I 76. 
być z nimi w ciężkiej dla nich chwili. Wierzymy, że śmierć jest początkiem lepszego życia, a nasza rozłąka ze zmarłymi jest przejściowa ${ }^{31}$.

Podczas obrzędów wstępnych w kaplicy kapłan składa wyrazy współczucia, przypominając, że bliscy zmarłego nie zostają sami ze swoim bólem i cierpieniem, lecz jest z nimi Bóg oraz wspólnota Kościoła. Przed liturgią Słowa kapłan kieruje do wiernych obecnych w kościele także słowa pociechy: „Boże, otwórz nasze serca na Twoje słowa, abyśmy w ciemnościach znaleźli światło, w naszych wątpliwościach pewność płynącą z wiary, w naszym smutku pociechę" ${ }^{2}$. Przede wszystkim obrzędy pogrzebu dają rodzinie zmarłego nadzieję na spotkanie z ukochanym zmarłym w niebie: „Niech to ostanie pożegnanie będzie wyrazem naszej miłości, ukoi nasz ból i umocni nadzieję. Kiedyś bowiem z miłością i radością spotkamy ponownie naszego brata (naszą siostrę) tam, gdzie śmierć zostanie pokonana przez miłość Chrystusa, która wszystko zwycięża”33.

W Instrukcji liturgiczno-duszpasterskiej Episkopatu o pogrzebie i modlitwach za zmarłych przedstawiony został cel pogrzebu: „Liturgia pogrzebu ma ścisły związek z przeżyciami wiernych. Jej celem jest nie tylko modlitwa za zmarłego, lecz także obudzenie wiary i nadziei członków jego rodziny i uczestników pogrzebu”34. Dlatego organizacja pogrzebu wiąże się z dwiema sferami, sacrum

${ }^{31}$ Obrzędy pogrzebu dostosowane do zwyczajów diecezji polskich, wyd. 2 uzup., Katowice 2002, $\mathrm{nr} 82$.

$3^{2}$ Obrzędy pogrzebu..., dz. cyt., nr 84 .

33 Obrzedy pogrzebu..., dz. cyt., nr 9o.C.

${ }^{34}$ Konferencja Episkopatu Polski, Instrukcja liturgiczno-duszpasterska Episkopatu o pogrzebie i modlitwach za zmarłych, 5.05.I978, w: Dokumenty duszpastersko-liturgiczne Episkopatu Polski (1966-1998), oprac. Cz. Krakowiak, L. Adamowicz, Lublin I9992 [dalej: Instrukcja], nr 5 . 
i profanum. Dla rodziny ważne są zarówno czynności dotyczące oprawy pogrzebu, jak i przygotowanie liturgiczne. Bliscy przywiązują wagę do wyboru trumny, pomnika, kwiatów czy zniczy, które są wyrazem uczczenia pamięci zmarłego oraz symbolem ich miłości do niego ${ }^{35}$. W przygotowaniu obrzędu pogrzebu należy uwzględnić życie zmarłego i okoliczności jego śmierci ${ }^{36}$. Rytuał przewiduje formuły dla gorliwych katolików, osób pełniących dzieła miłosierdzia, zawiera też zbiór różnorodnych pieśni i modlitw ${ }^{37}$.Znaczenie ma również dobór czytań podczas liturgii, które powinny nawiązywać do życia zmarłego ${ }^{38}$. Duszpasterz przyjmujący w kancelarii parafialnej zgłoszenie o pogrzebie powinien wykazać się szczerym współczuciem dla rodziny zmarłego oraz zorientować się, czy nie potrzebuje ona wsparcia materialnego ${ }^{39}$. Zachowanie osób, które rodzina spotyka w czasie między śmiercią a pogrzebem, jest szczególnie ważne dla sposobu przeżywania żałoby. Okazywanie szczerego zainteresowania i wsparcia wpływa pozytywnie na uporanie się z doświadczeniem utraty bliskiej osoby $^{40}$.

Pogrzeb stanowi próbę „zatrzymania” zmarłego, stworzenia przestrzeni pomiędzy nim a żyjącymi ${ }^{4}$. Po śmierci nie jest już możliwe utrzymywanie relacji ze zmarłym, dlatego jej brak staje

${ }^{35}$ Por. A. Wedeł-Domaradzka, Śmierć a prawa cztowieka, Toruń 2010, S. I 93 .

${ }^{36}$ Por. Instrukcja, nr 8.

${ }_{37}$ Por. Instrukcja, nr 8.

${ }^{38}$ Por. Instrukcja, nr 9.

${ }^{39}$ Por. Instrukcja, $\mathrm{nr} 5$.

${ }^{40}$ Por. B. Imielska, Umartych pogrzebać. Zagadnienie pochówku dzieci poronionych..., dz. cyt., s. I59.

${ }^{41}$ Por. J. Pawlik, Zatrzymać i oddalić. Podwójna logika obrzędowości żatob$n e j . . .$, dz. cyt., s. I64. 
się podstawą do wykreowania nowej więzi dzięki przyznaniu zmarłemu miejsca wśród umarłych ${ }^{42}$. Pogrzeb uświadamia bliskim, że odtąd trzeba inaczej pojmować osobę, która odeszła. Dlatego też rytuały pogrzebowe stają się sposobem „zatrzymania” zmarłego pośród żyjących, ale już w nowej formie obecności. Służy temu zakopanie ciała w ziemi i przykrycie płytą grobową. Wyznaczenie miejsca pochówku gwarantuje, że ciało zmarłego tam już zostanie ${ }^{43}$. Pochowanie ciała na cmentarzu obrazuje również oddzielenie świata zmarłych od żywych i jest nadaniem zmarłemu nowego statusu ${ }^{44}$. Krewni posiadający w domu urnę z prochami są nadal zależni mentalnie i fizycznie od osoby, która umarła. Wciąż próbują podtrzymywać istniejąca przd śmiercią relację, nie potrafiąc właściwie przeżyć żałoby. Pogrzeb reorganizuje dotychczasowe relacje ze zmarłym poprzez wyznaczenie mu miejsca pochówku i pożegnanie się z nim.

Prawo do pogrzebu kościelnego przysługuje osobie, która zmarła, jak i rodzinie oraz wspólnocie kościelnej45. Wspólnota kościelna może domagać się pogrzebu danej osoby, jeśli nie istnieją okoliczności, które mogłyby uzasadniać odmówienie jej pogrzebu kościelnego, np. trwanie w jawnym grzechu ciężkim ${ }^{46}$. Czynności poprzedzające pogrzeb oraz sama ceremonia stanowią ostatnie pożegnanie ze zmarłym. Pogrzeb jest wyrazem miłości

${ }^{42}$ Por. J. Pawlik, Zatrzymać i oddalić. Podwójna logika obrzędowości żatob$n e j . . .$, dz. cyt., s. I64.

${ }_{43}$ Por. J. Pawlik, Zatrzymać i oddalić. Podwójna logika obrzędowości żatob$n e j . . .$, dz. cyt., s. I 65 .

${ }^{44}$ Por. J. Pawlik, Zatrzymać i oddalić. Podwójna logika obrzędowości żatobnej..., dz. cyt., s. I 66.

${ }_{45}$ Por. J. Gołąb, Prawo do pogrzebu i jego wykonanie w prawie kanonicznym ipolskim, Rzeszów 2004, s. 78.

${ }^{46}$ Por. J. Gołąb, Prawo do pogrzebu i jego wykonanie..., dz. cyt., s. 79. 
osób żyjących do osoby zmarłej, uczczeniem jej pamięci oraz okazaniem szacunku wobec jej ciała. Dlatego sposób organizacji i przygotowania się do niego odgrywają kluczową rolę w procesie żałoby. Podczas przeżywania żałoby bliscy powinni zrozumieć, że nie będą już mieli relacji z osobą, którą odeszła, ale pamięć o niej pozostaje. Te dwa ważne aspekty są uwzględnione w rytuale pogrzebu, który nie tylko chroni godność zmarłego, lecz także uwzględnia uczucia bliskich.

Dzisiejsze zmiany w obchodzeniu się ze zmarłym oraz organizacji ceremonii pogrzebu mogą powodować wydłużenie się procesu żałoby lub niewłaściwe jej przeżycie. Współcześnie ciałem zmarłego oraz organizacją pogrzebu zajmują się zakłady pogrzebowe. Obrzędowość związana z samym pogrzebem stała się uboższa: nie ma już czuwania i modlitw w domu przy zmarłym, nie praktykuje się także pochodu za trumną $z$ domu zmarłego do kościoła ${ }^{47}$. Modna stała się masowa kremacja, szczególnie popularna w kulturze zachodniej ${ }^{48}$. Uroczystości pogrzebowe niejednokrotnie przyjmują charakter komercyjny, ważniejsza jest oprawa niż pożegnanie zmarłego. Wskazane powyżej zmiany kreują nową obrzędowość żałobną, która najczęściej pomija sferę uczuć krewnych i ma na celu skrócenie żałoby. Nowe formy ostatniego pożegnania pokazują także, jaką wartość dla społeczeństwa ma dziś życie człowieka oraz ciało po śmierci ${ }^{49}$. Instrumentalne traktowanie zwłok ludzkich nie przyśpieszy procesu żałoby i nie ukoi bólu po stracie bliskiej osoby. Pożegnanie z szacunkiem zmarłego umożliwia oswojenie się ze śmiercią i brakiem bliskiej osoby.

\footnotetext{
${ }_{47}$ Por. A. Wedeł-Domaradzka, Śmierí a prawa cztowieka, dz. cyt., s. 202.

${ }^{4}$ Por. A. Wede1-Domaradzka, Śmierć a prawa cztowieka, dz. cyt., s. I98.

${ }_{49}$ Por. P. Morciniec, Bioetyka personalistyczna wobec zwtok ludzkich, s. I 84 .
} 


\section{Bibliografia}

Barański J., Śmierć i zmysty. Doświadczenie śmiertelnej choroby i śmierci na przestrzeni wieków, w: Śmierć i wiara w życie pośmiertne w świetle nauk przyrodniczych i humanistycznych, red. M. Machinek, Olsztyn 2003, s. I35-156.

Codex Iuris Canonici, auctoritate Ioannis Pauli PP. II promulgatus, 25.0I.I983, AAS 75 (I983), pars II, wyd. pol. Kodeks prawa kanonicznego, przekład polski zatwierdzony przez Konferencję Episkopatu, Poznań 2008.

Gołąb J., Prawo do pogrzebu i jego wykonanie w prawie kanonicznym i polskim, Rzeszów 2004.

Imielska B., Umartych pogrzebać. Zagadnienie pochórwku dzieci poronionych lub martwo urodzonych w prawie kanonicznym oraz ustawodawstwie polskim, Bielsko-Biała 2014.

Katechizm Kościoła katolickiego, wyd. pol. Poznań 2002.

Konferencja Episkopatu Polski, Instrukcja liturgiczno-duszpasterska Episkopatu o pogrzebie i modlitwach za zmarłych, 5.05.I978, w: Dokumenty duszpastersko-liturgiczne Episkopatu Polski (I966-I998), oprac. Cz. Krakowiak, L. Adamowicz, wyd. 2 Lublin I999, s. 279-283.

Makselon J., Fatum czy szansa? Postawy wobec wtasnej śmierci, w: Śmierć i wiara w życie pośmiertne w świetle nauk przyrodniczych i humanistycznych, red. M. Machinek, Olsztyn 2003, s. 33-44.

Morciniec P., Bioetyka personalistyczna wobec zwtok ludzkich, Opole 2009.

Nadolski B., Leksykon liturgii, Poznań 2006.

Obrzędy pogrzebu dostosowane do zwyczajów diecezji polskich. Wydanie drugie uzupełnione, Katowice 2002.

Ogryzko-Wiewiórowska M., Desocjalizacja umierania. Aspekty socjologiczne kresu życia, w: Śmierć i wiara w życie pośmiertne w świe- 
tle nauk przyrodniczych i humanistycznych, red. M. Machinek, Olsztyn 2003, s. 69-83.

Ostrowska A., Śmierí w doświadczeniu jednostki i spoteczeństwa, Warszawa I999.

Pawlik J., Zatrzymać i oddalić. Podwójna logika obrzędowości $\dot{z}$ atobnej, w: Śmierći wiara w życie pośmiertne w świetle nauk przyrodniczych i humanistycznych, red. M. Machinek, Olsztyn 2003, s. $157-\mathrm{I} 72$.

Rudnicki Z., Śmierí jako kres życia ludzkiego, w: Wybrane problemy osób starszych, red. A. Nowicka, Kraków 2006, s. 99-I20.

Wedeł-Domaradzka A., Śmierí a prawa człowieka, Toruń 2010. 